\title{
The basic ability of the executive secretary of a new era
}

\author{
Yongming $\mathrm{Xu}$ \\ Dalian Vocational and Technical College, 116035, China
}

Key words: New era; Colleges and universities; The executive secretary; Basic ability

Abstract: The executive secretary of colleges and universities is the connection link between school's leaders and teachers, students, that is not only to report to the leadership of the work, but also to understand the needs of teachers and students. Because of the development of education reform in the new era, the secondary management model is formed in colleges and universities, and the requirements of the executive secretary is even higher. This article mainly aims at the executive secretary of the basic ability of colleges and universities, describe what capabilities the administrative secretary of the new era should have, at the same time, analysis how to improve the executive secretary of the basic ability, so as to improve the work efficiency.

\section{Introduction}

The management mode of new age colleges is the secondary management model of the college, so the administrative secretary of the college has more responsibilities. Such as the development of various decision-making in college, management of daily teaching, personnel management, etc, although these jobs are not the responsibility of the executive secretary, but because of the large workload and more cumbersome, the administrative secretary easy to work in the boredom and the efficiency will be low, seriously affect the development of the college. Therefore, first of all to understand the basic ability of the new era of administrative secretary and then take reasonable measures to enhance these abilities to improve the quality of the work.

\section{The basic competence of the administrative secretary of a new era}

\subsection{The business capacity of the administrative secretary of the university}

First, the executive secretary should have the corresponding business ability, which is the comprehensive career ability. Business ability, including the leadership of the faculty, the teacher to communicate, coordinate the relationship between the faculties and the leadership, as well as the drafting of the revised documents, writing documents, scheduling meetings, computer operations and a variety of information processing capabilities[1]. The comprehensive ability is measure key elements of an administrative secretary is qualified, only these business capabilities to meet the requirements of college work, the executive secretary to carry out daily work effectively, handling routine tasks.

\subsection{The administration secretary should have the ability of management}

The executive secretary of colleges and universities is also related to management positions, because the executive secretary needs to handle a lot of things, including daily work, but also deal with emergency events, arrange temporary meetings, reception guests and so on. Sometimes more than one thing, is likely to be disrupted because of the plan and become rush, frequent problems, can not do the work of convergence. So the executive secretary of colleges and universities must have strong ability of management, not only manage the relevant matters on the job, but also to manage their own work, reasonable arrangements for the time, do a good job in dealing with emergencies ahead of the plan, continue to learn from experience. Such as the college in the conduct of teacher appraisal and held various activities, when the time will be busy, the executive secretary is not only responsible for the daily administrative work, but also organizing and coordinating the activities of this stage and tracking reports. How does the executive secretary arrange other administrative affairs on the basis of not affecting the daily work, and will require the executive secretary to exercise in the ordinary management. 


\subsection{The organization and coordination ability of the administrative secretary of the university}

Of course, the administrative secretary of the university is the senior leader and the school teacher, the student's dual leader, and must have the higher organization and coordination ability. These capabilities include communication with various departments, academic leaders and teachers, for example, the executive secretary must have a high level of organization and coordination due to heavy work and time constraints when there is a full school sexual activity. Timely communication with the relevant departments or leadership, correctly understand detailed activity information, reflect the problem to your supervisor in time, if the leadership is busy, then pay attention to grasp the time, and should pay attention to the way in communication with other departments. In addition, the coordination and coordination of the administrative secretary is also reflected in the daily reception work, conference arrangement, event organization. For example, in daily work, even trivial matters should be arranged carefully, before the start of the meeting or activities, communicate with relevant personnel, prepare in advance, organize meetings or events in a timely manner. Of course, if there are any problems during the meeting or event, on the one hand, it is prepared in advance and on the other hand there is a certain amount of temporary reaction and ability to deal with the crisis[2]. Such as during the organization of the college teacher meeting, you need to understand in advance the time of the teacher attending the meeting and communicate with the teacher to see if you can adjust the time. How to deal with the teacher's temporary things, the administrative secretary is not going to understand the specific situation, if the majority of teachers absent the meeting, the executive secretary needs to weigh the meeting to continue or to cancel, if canceled, how to solve the impact of the cancellation of the meeting.

\subsection{The administrative secretary should have the psychological adjustment ability}

In addition, the administrative secretary of the university should have some psychological adjustment ability. Because the job of the executive secretary is trivial and important, sometimes there will be the accumulation of the task of the situation. No matter what kind of situation encountered, as an executive secretary, you must be able to control your emotions and not bring personal negativity into your work. For example, when you have a bad mood, but also learn to control your own behavior and work attitude, in dealing with leadership relations should pay attention to the way, should start from the global, considering the interests of all parties, love work and collective. In particular, the university administration secretary has the following characteristics when regulating oneself psychology emotion. First of all, you must love your job, only love the work, can do the daily administrative affairs well, can really start from the work point of view, not subject to external interference, completes own labor of duty, great to complete the task from leadership. Second, must have the strong will, the executive secretary of colleges and universities may appear mistakes in the daily work, or there may be some difficulties due to the task too much and more difficult. This time you need to adjust your mood and control your own behavior, does not choose to escape because of problems or difficulties, complain or even careless. In addition, the executive secretary of colleges and universities should have positive work attitude, it is the request of administrative secretarial work, also is the need of administrative secretary for self-growth. For example, to treat everyone or anything with normal mind, can not be negative and retreat because hate something, need to dare to face the challenging things. Whether faced with a leader or a teacher or a student, the executive secretary must always maintain an administrative attitude and cannot be controlled by their own emotions[3].

\section{Strengthen the service consciousness of the administrative secretary of university}

The executive secretary of colleges and universities have a lot of the basic ability, especially in the new era, the executive secretary must learn to constantly break through his own, enhance his professional ability, so as to improve work efficiency. First, the administrative secretary of the university should enhance the sense of service. On the one hand, the executive secretary need to change the traditional ideas and realize the importance of their work, at work, not only will you be responsible for the leadership of the college, but also the teachers and students, so we have to 
establish a sense of service and correct attitude, actively serve the leadership and the teachers and students. On the other hand, the executive secretary of colleges and universities to learn in-depth teaching practice, understand the needs of teachers and students, take the initiative to communicate with other departments or the executive secretary of the college, take the initiative to report problems to the relevant leadership, which can improve service depth and quality, better spread the relevant spirit of the college to teachers and students. For example, the college wants to issue new management treaties, there is a new requirement for teachers and students to teach and learn everyday, at this time the executive secretary as a link between the college and teachers and students, you need to take the initiative to serve them, actively cooperate with the leadership of the management reform, and then the relevant regulation policy through the right means of propaganda to the teachers and students, feedback for teachers and students should be summarized and then submitted to the school leadership.

\section{Strengthen their own learning and improve the basic ability}

Today is an age of information that is rapidly evolving and changing, the executive secretary of colleges and universities wants to improve their professional ability, in addition to making a change in thought, we must improve through practice. Such as in the information technology era, the management of colleges and universities began to enter the paperless, automated, the executive secretary in dealing with various affairs in order to improve the work efficiency, need to be familiar with master computer operation technology. Such as in addition to the basic information input and tracking, also need to learn to use a variety of teaching, administration and management software, learning the appropriate scientific knowledge. Only with the relevant scientific knowledge, we can keep up with the times, not only improve the work efficiency, but also can reduce the pressure of the job, better to go into work. In addition, the administrative secretary of the university should also learn the relevant management knowledge. The administrative secretary may not be a manager of professional origin when recruiting, and management experience is relatively less, although the administrative secretary of the university is an administrative post, but also need to participate in a lot of management work. So learning management science, personnel management, file management and other knowledge, make administrative work more consistent and orderly, work efficiency is better.

\section{Conclusion}

In summary, in the new era, the administrative secretary of the university mainly has the management ability, communication and coordination ability, psychological adjustment ability and business ability including computer operation, information processing, document writing and so on. Since the new age has put forward new requirements for the work of the administrative secretary of the university, so we need to enhance these basic capabilities by improving service awareness and strengthening learning.

\section{References}

[1] Chen Bin. How to improve the efficiency of the administrative secretaries in colleges and universities [J]. Energy, 2012 (10): 79.

[2] Tang Jianlin. To discuss the work of the executive secretary of the secondary college. [J]. Journal of Jiamusi Education Institute, 2001, (6) : 75-76.

[3] Lou Chenjun. To discuss the quality of administration secretarial training in the new period. [J]. Science and technology, 2011 (10) : 186. 